Sains Malaysiana 47(9)(2018): 1941-1951

http://dx.doi.org/10.17576/jsm-2018-4709-01

\title{
Water Quality Influences on Fish Occurrences in Sungai Pahang, Maran District, Pahang, Malaysia
}

(Pengaruh Kualiti Air ke atas Keterdapatan Ikan di Sungai Pahang, Daerah Maran, Pahang, Malaysia)

\author{
Zulkafli Abdul RASHid, MoHAmmad NoOR AZMAi AMAL* \& SHAMARINA SHOHAimi
}

\begin{abstract}
This study assesses the influence of water quality on fish occurrences in Sungai Pahang, Maran District, Pahang, Malaysia. Water quality and fish samplings were conducted at seven sampling sites in the district for 13 consecutive months. We used canonical correspondence analyses (CCA) to determine the influence of water quality on monthly fish species occurrences. The ranges of water quality parameters were quite high considering the measurements were made during rainy and dry seasons throughout the year. A total of 2,075 individual fish was captured which comprised of 22 different families and 65 species. Family Cyprinidae recorded the highest number of fish species of the area (27 species; 41.5\%), followed by Bagridae (five species; 7.69\%) and Pangasiidae (five species; 7.69\%). Three fish species categorized as endangered, including Balantiocheilos melanopterus, Probarbus jullieni and Pangasianodon hypophthalmus were also collected. The collected fish species were divided into three groups (A to C), which was clearly separated in the CCA ordination diagram. The most important water quality variables for the fish occurrences in this river were $\mathrm{pH}$, followed by temperature, conductivity, alkalinity and phosphate. Data analysis indicates that the occurrence of fishes were influenced by a combination of water quality parameters, but not associated with sampling month. The results present a new data from a study of fish assemblage and their habitat condition which may be important in fisheries activity and fish conservation of the river in the future.
\end{abstract}

Keywords: Fish assemblages; fish occurrences; Malaysia; Sungai Pahang; water quality

\section{ABSTRAK}

Kajian ini menilai pengaruh kualiti air pada keterdapatan ikan di Sungai Pahang, Daerah Maran, Pahang, Malaysia. Persampelan kualiti air dan ikan telah dijalankan di tujuh tapak pensampelan di daerah ini selama 13 bulan berturutturut. Kami menggunakan analisis penghubungan berkanun (CCA) untuk menentukan pengaruh kualiti air pada keterdapatan spesies ikan setiap bulan. Julat parameter kualiti air adalah agak tinggi memandangkan pengukuran dibuat semasa musim kering dan hujan sepanjang tahun. Sebanyak 2,075 individu ikan telah berjaya ditangkap yang terdiri daripada 22 famili dan 65 spesies yang berbeza. Famili Cyprinidae merekodkan bilangan tertinggi spesies ikan di kawasan tersebut (27 spesies; 41.5\%), diikuti oleh Bagridae (lima spesies; 7.69\%) dan Pangasiidae (lima spesies; 7.69\%). Tiga spesies ikan yang dikategorikan sebagai terancam, termasuk Balantiocheilos melanopterus, Probarbus jullieni dan Pangasianodon hypophthalmus turut dikumpul. Spesies ikan yang dikumpul dibahagikan kepada tiga kumpulan (A hingga C), yang secara jelas telah dipisahkan di dalam gambarajah penyelarasan CCA. Pemboleh ubah kualiti air terpenting untuk keterdapatan ikan di sungai ini ialah $\mathrm{pH}$, diikuti dengan suhu, kekonduksian, kealkalian dan fosfat. Analisis data menunjukkan bahawa keterdapatan ikan dipengaruhi oleh gabungan parameter kualiti air, tetapi tidak berkaitan dengan bulan persampelan. Keputusan menunjukkan data yang baharu daripada kajian kumpulan ikan dan keadaan habitat yang mungkin penting dalam aktiviti perikanan dan pemuliharaan ikan sungai pada masa hadapan.

Kata kunci: Keterdapatan ikan; kualiti air; kumpulan ikan; Sungai Pahang; Malaysia

\section{INTRODUCTION}

Understanding of fish-habitat relationships is crucial for management and conservation of fish (Wildhaber et al. 2000). Due of the specific habitat requirements, fish species strongly depend on the characteristics of water and its dynamics and they have long been used to quantify the effect of disturbance on the environment (Magoulick 2004; Smol 2010). Fish has been proven to be a suitable indicator of habitat conditions and can be used in environmental planning (Schiemer 2000).

The factors influencing the abundance and diversity of riverine fishes can be divided into physical, chemical, biological and zoogeographic factors (Moyle \& Cech 2003). Studies have shown that variability in fish assemblages were generally influenced by the stream size and elevation (Brown 2000), stocking of economically 
important fishes (Pivnička \& Humpl 2004), landscape features and physical habitat structure (Angermeier \& Winston 1999; Humpl \& Pivnička 2006) and water qualities (Dubey et al. 2012; Fischer \& Paukert 2008; Li et al. 2012; Sutela et al. 2010).

Previous studies showed that water quality play an important role in fish assemblages in a habitat or aquatic ecosystem. For example, in boreal rivers in Finland, the total phosphorus and oxygen saturation in winter had the highest influence on fish assemblages (Sutela et al. 2010), while in the upper Brazos River of a prairie ecosystem and Great Plain rangeland regions in US, it has been observed that water conductance and conductivity was related to fish assemblages of the water area, respectively (Fischer \& Paukert 2008; Ostrand \& Wilde 2002). In a mountain stream of north Tiaoxi River, China, a study showed that water $\mathrm{pH}$ had significant relationships with the fish assemblages ( $\mathrm{Li}$ et al. 2012), whereas the water temperature and transparency explained the seasonal and spatial changes in fish abundance in wetland of Cross River, Nigeria (Offem et al. 2009). In a tropical habitat in small rivers in eastern Thailand, a study showed that fish species richness was negatively and positively related with $\mathrm{pH}$ and dissolved oxygen, respectively, while relative abundance was inversely related with ambient ammonia and directly related with ambient oxygen and alkalinity (Tongnunui \& Beamish 2009).

Malaysia is known to be among the mega-diverse countries in terms of flora and fauna. This country possesses various ecosystems and habitats suitable for various life forms, including the fish fauna (Ambak et al. 2010). Inland water bodies and wetlands including rivers, lakes, peat swamps, swamps, reservoirs, former mining pools, irrigation canals and paddy fields occupy a total surface area of $45,459 \mathrm{~km}^{2}$ (Yusoff \& Gopinath 1995). The large expanse of water space and varied aquatic habitats provide good opportunity for fish colonization. A total of 413 freshwater species (belonging to 178 families) has been identified in this country (Ambak et al. 2010). However, freshwater habitats encompass the highest percentage of threatened fish species. Studies reported that there were 32 species of highly threatened fishes in this country where $50 \%$ of the species were from freshwater environment (Chong et al. 2010).

Sungai Pahang in Pahang is the longest river in Peninsular Malaysia. The river begins at the confluence of Sungai Jelai and Sungai Tembeling of Titiwangsa mountains and drains into the South China Sea. At 459 $\mathrm{km}$ in length, this river flows through Pahang and is well known for its richness in ichthyofauna. This river provides an important habitat for protection and breeding of several commercial species of fishes and aquaculture purposes (Haslawati et al. 2007). The fish collection of Sungai Pahang has been documented by Zulkafli et al. (2014). From their report, a total of 60 species of fish has been identified from this river, which encompasses about $14.5 \%$ of freshwater fishes in this country. However, the previous reports on fishes in this river were for inventory purposes only, rather than identifying the influence of the habitat on fish assemblages (Zulkafli et al. 2015, 2014).

Maran is a district located in the center of Pahang, Peninsular Malaysia. This district is located between the district of Temerloh and Kuantan. The district covers an area about $1,995.59 \mathrm{~km}^{2}$, while Sungai Pahang also flows through it. Maran is surrounded by isolated forest and oil palm plantations, while the main economy activities in this district focus on agriculture, farming and fishing, which may be the major point sources of pollution in this area (MDC 2015). This study evaluates the influence of water quality on fish occurrences in Sungai Pahang, Maran district, Pahang, Malaysia.

\section{MATERIALS AND METHODS}

\section{STUDY AREA}

Seven sampling points were randomly chosen for fish sampling along the Sungai Pahang in Maran District (Site 1: 3²9'52.7'N 10246'49.0”E; Site 2: 3²9'58.3”N

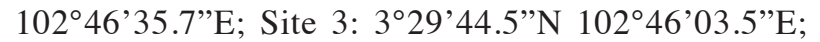
Site 4: $3^{\circ} 30^{\prime} 08.2^{\prime \prime N} 102^{\circ} 45^{\prime} 05.9^{\prime \prime} \mathrm{E}$; Site 5: 3०30'16.3”N 10243'59.9'"E; Site 6: 3॰30'41.8”N 10242'55.0"E; Site 7: $3^{\circ} 30^{\prime} 57.5^{\prime \prime} \mathrm{N} 102^{\circ} 41^{\prime} 53.1$ 'E) (Figure 1). The distance from the easternmost site (Site 1) and west site (Site 7) was approximately $10 \mathrm{~km}$, while the distance between each sampling site was around 1.0 to $1.5 \mathrm{~km}$. All of the sampling sites were clustered along the river in this district in order to obtain the most representative fish species of the area. All sites were also road accessible and located in the relatively undisturbed area. All of the sampling sites were characterized by a large river with deep slow reaches, a river bed that is usually covered with sand or gravel substrates and no tidal influence.

\section{WATER QUALITY AND HABITAT CHARACTERIZATION}

Water quality variables were measured at the same site where the fish were sampled, specifically after the installation of the fishing nets for fish capture. A total of nine water quality parameters were determined. Water quality parameters were measured in situ using a handheld YSI meter (YSI, Yellow Springs, OH, USA), which included water temperature $\left({ }^{\circ} \mathrm{C}\right)$, dissolved oxygen $(\mathrm{DO})(\mathrm{mg} / \mathrm{L})$, conductivity $(\mu \mathrm{S} / \mathrm{cm})$, alkalinity $(\mathrm{mEq} / \mathrm{l})$ and $\mathrm{pH}(1-14)$. Water samples were collected into $200 \mathrm{~mL}$ polyethylene bottles using a water sampler (Wildco, Yulee, FL, USA), then measurement of ammonia $(\mathrm{mg} / \mathrm{L})$, nitrate $(\mathrm{mg} / \mathrm{L})$, sulfide $(\mathrm{mg} / \mathrm{L})$ and total suspended solids (TSS) $(\mathrm{g} / \mathrm{L})$ concentrations were conducted using a spectrophotometer (HACH Company, Loveland, CO, USA).

\section{FISH SAMPLING}

Fish samplings were conducted for 13 consecutive months, at monthly intervals from July 2005 to July 2006. The depths of water at sampling points ranged from 0.9 to $10.1 \mathrm{~m}$, with the mean \pm standard deviation at $4.11 \pm$ 


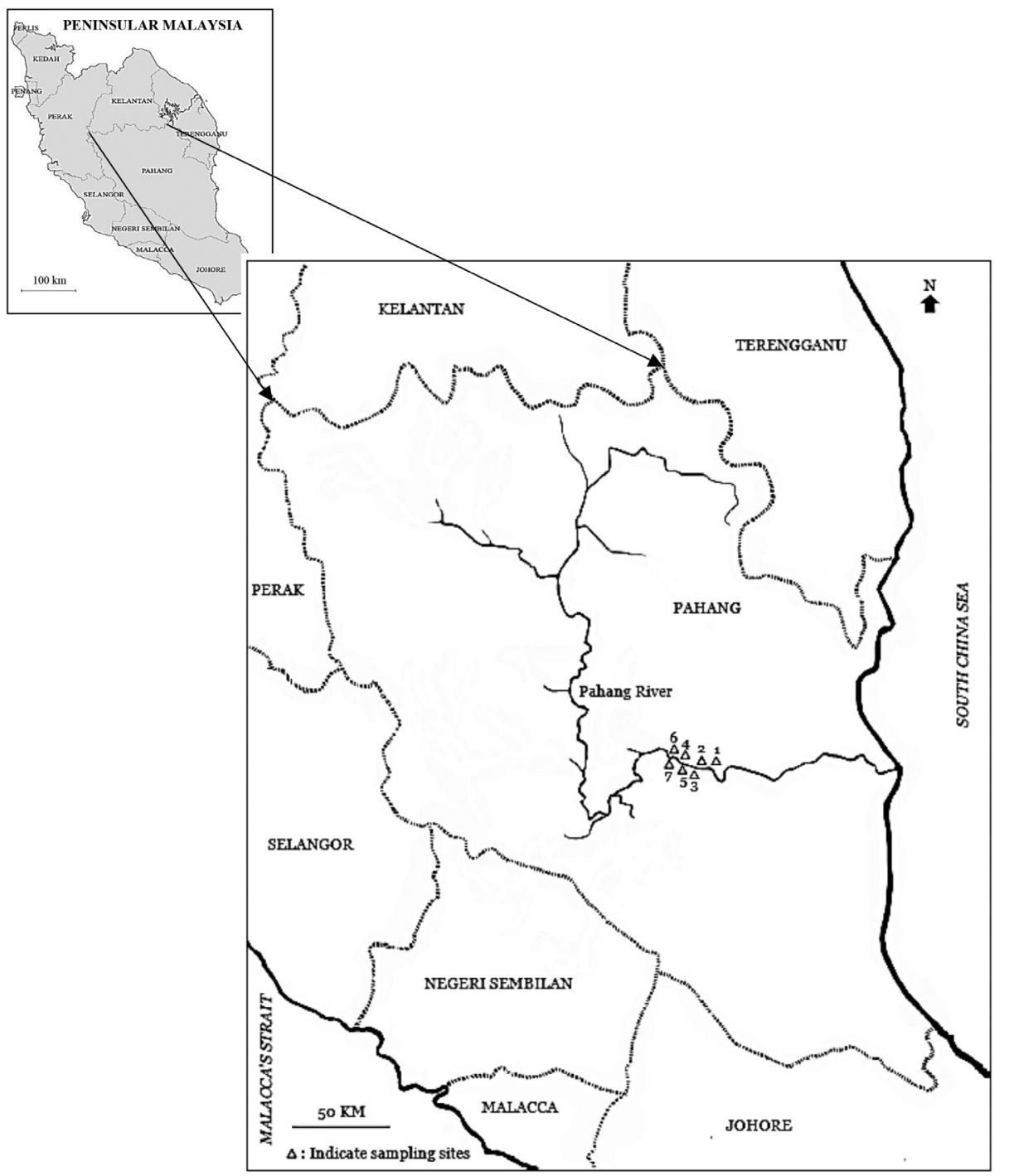

FIGURE 1. Location of sampling sites in Sungai Pahang, Maran District, Pahang, Peninsular Malaysia

$2.67 \mathrm{~m}$. The drift and static gill nets (between 15 and 30 $\mathrm{m}$ long and 2.5 to $4.0 \mathrm{~m}$ width), ranging from 2.5 to 13.0 $\mathrm{cm}$ between knots were used at each sampling points. Due to quite high number of sampling sites that are situated along the river and human labor issues, at each sampling site, the gill nets cannot be set at the same time, but they were set between 7.00 AM and 10.00 AM on the same day. The nets were checked for captured fish at every 7 to 10 $\mathrm{h}$, and maintained in the position for $24 \mathrm{~h}$ of sampling time (Zulkafli et al. 2015).

Fish that could confidently be identified were enumerated and if still alive, were released back to their natural environment. The fishes that could not be identified in the field were fixed in $10 \%$ formalin and later transferred to ethanol $70 \%$ for permanent storage in the fish collection of Freshwater Fisheries Research Center, Fisheries Research Institute, Jelebu, Negeri Sembilan. The samples were then transported back to the laboratory for further counting and taxonomic identification based on Ambak et al. (2010) and Froese and Pauly (2014). The latest taxonomical names of the fishes were referred to
Kottelat (2013) and Froese and Pauly (2014), while the threat statuses of all the collected fish were based on The IUCN Red List of Threatened Species (IUCN 2015). Total length of each fish was measured to the nearest $0.1 \mathrm{~cm}$ with a slide caliper and the individual body weight was recorded to the nearest $0.1 \mathrm{~g}$ using an electronic digital balance.

\section{STATISTICAL ANALYSIS}

The percentage of collected fish for each species from the total collected fishes and percentage of occurrence during 13 months of sampling duration were calculated. Then, in order to identify the relationship between water quality and fish occurrences, nine water qualities were taken into consideration, including $\mathrm{pH}$, temperature, DO, conductivity, alkalinity, ammonia, nitrate, phosphate and TSS. Dataset comprised of numerous variables is likely quite redundant if two or more variables have a high correlation to each other. Principal components analysis (PCA) using SPSS (Version 22) was performed to reduce the number of variables in a dataset while retaining the variability in the 
data. By using PCA, the variables that are correlated with one another are combined into factors.

The relationships between water qualities, time of fish sampling and fish species occurrences in each sampling time were then analyzed using canonical correspondence analysis (CCA). The CCA was examined using XLSTAT add-in for Microsoft Excel. For this analysis, only water qualities that showed variation in their values along the river were used. The significance of each variable was tested using CCA in XLSTAT-ADA with 5000 permutations at a significance level of $5 \%$. The results are presented using Canonical biplots and other descriptive statistics.

\section{RESULTS}

\section{WATER QUALITY AND HABITAT CHARACTERIZATION}

The water quality parameters data from each sampling site and overall readings (Site 1 to Site 7) are presented in Table 1. For the overall water qualities readings, the sampling sites in this area demonstrated acidic water where the mean of $\mathrm{pH}$ reading was at $6.44 \pm 0.59$ and ranged from 5.00 to 8.45 . The range of water temperature $\left(24.80\right.$ to $\left.34.40^{\circ} \mathrm{C}\right)$ and DO (4.85 to $9.30 \mathrm{mg} / \mathrm{L})$ were quite high considering the measurement from rainy and dry seasons during the year with the mean at $28.64 \pm 1.93^{\circ} \mathrm{C}$ and $6.99 \pm 1.06$ $\mathrm{mg} / \mathrm{L}$, respectively. The mean of water conductivity was about $89.63 \pm 19.71 \mu \mathrm{S} / \mathrm{cm}$, where the range was about 1.5 times from the lowest measurement, which was 50.00 $\mu \mathrm{S} / \mathrm{cm}$. For alkalinity, the range were about four times from the lowest measurement $(11.00 \mathrm{mEq} / \mathrm{L})$, with the mean $20.80 \pm 5.66 \mathrm{mEq} / \mathrm{L}$. The mean reading of ammonia, nitrate, phosphate and TSS were $0.71 \pm 0.31 \mathrm{mg} / \mathrm{L}, 1.41$ $\pm 2.11 \mathrm{mg} / \mathrm{L}, 0.81 \pm 1.92 \mathrm{mg} / \mathrm{L}$ and $102.46 \pm 62.40 \mathrm{~g} / \mathrm{L}$, respectively, while the ranges of these four measurements were also considered wide.

The PCA produced two axes that cumulatively explained $66.78 \%$ of the environmental variation in the study area (Table 2). The first axis had high loadings for temperature, alkalinity and phosphate. With the exception of temperature, the second axis had high loadings for all the water quality parameters that were measured. All of the five variables had high loadings on at least one of the principal component axis interpreted.

\section{FISH OCCURRENCES}

A total of 2,075 individual fish was captured during the study. The fishes were from 22 different families and 65 species (Table 3). Family Cyprinidae recorded the highest number of fish species (27 species; $41.5 \%$ ) followed by

TABLE 1. Measurement of water quality parameters at Sungai Pahang, Maran District, Pahang

\begin{tabular}{lccccccccc}
\hline Variables & Site 1 & Site 2 & Site 3 & Site 4 & Site 5 & Site 6 & Site 7 & \multicolumn{2}{c}{ Overall readings (Site 1 - Site 7) } \\
\cline { 2 - 9 } & \multicolumn{7}{c}{} & \multicolumn{3}{c}{ Mean } & & & & \multicolumn{2}{c}{ Mean \pm SD } & Range \\
\hline pH $(1-14)$ & 6.58 & 6.39 & 6.30 & 6.46 & 6.42 & 6.45 & 6.48 & $6.44 \pm 0.59$ & $5.00-8.45$ \\
Temperature $\left({ }^{\circ} \mathrm{C}\right)$ & 28.87 & 28.68 & 28.68 & 28.39 & 28.41 & 28.37 & 28.64 & $28.64 \pm 1.93$ & $24.80-34.40$ \\
DO $\left(\mathrm{mg} \mathrm{L}^{-1}\right)$ & 7.17 & 7.04 & 6.97 & 6.82 & 7.10 & 6.95 & 6.91 & $6.99 \pm 1.06$ & $4.85-9.30$ \\
Conductivity $\left(\mu \mathrm{S} \mathrm{cm}^{-1}\right)$ & 89.00 & 89.08 & 89.31 & 91.38 & 88.77 & 87.46 & 92.38 & $89.63 \pm 19.71$ & $50.00-125.00$ \\
Alkalinity $\left(\mathrm{mEq} \mathrm{L}^{-1}\right)$ & 20.77 & 20.38 & 20.15 & 20.62 & 20.31 & 22.62 & 20.77 & $20.80 \pm 5.66$ & $11.00-44.00$ \\
Ammonia $\left(\mathrm{mg} \mathrm{L}^{-1}\right)$ & 0.70 & 0.76 & 0.70 & 0.73 & 0.75 & 0.64 & 0.66 & $0.71 \pm 0.31$ & $0.09-1.53$ \\
Nitrate $\left(\mathrm{mg} \mathrm{L}^{-1}\right)$ & 1.43 & 1.48 & 1.52 & 1.48 & 1.30 & 1.31 & 1.39 & $1.41 \pm 2.11$ & $0.00-6.50$ \\
Phosphate $\left(\mathrm{mg} \mathrm{L}^{-1}\right)$ & 0.94 & 1.40 & 0.69 & 0.53 & 0.56 & 0.56 & 1.02 & $0.81 \pm 1.92$ & $0.04-13.65$ \\
TSS $\left(\mathrm{g} \mathrm{L}^{-1}\right)$ & 95.46 & 105.00 & 112.54 & 100.23 & 96.92 & 100.38 & 106.69 & $102.46 \pm 62.40$ & $15.00-315.0$ \\
\hline
\end{tabular}

TABLE 2. Principal component loadings from principal component analysis of water quality parameters

\begin{tabular}{lcc}
\hline & PC1 & PC2 \\
\hline $\mathrm{pH}$ & -0.18 & $\mathbf{0 . 8 5}$ \\
Temperature $\left({ }^{\circ} \mathrm{C}\right)$ & $\mathbf{- 0 . 7 7}$ & 0.01 \\
Conductivity $(\mu \mathrm{S} / \mathrm{cm})$ & -0.16 & $\mathbf{- 0 . 8 3}$ \\
Alkalinity $(\mathrm{mEq} / \mathrm{L})$ & $\mathbf{0 . 7 6}$ & -0.26 \\
Phosphate $(\mathrm{mg} / \mathrm{L})$ & $\mathbf{0 . 7 4}$ & 0.28 \\
Eigenvalue & 1.78 & 1.56 \\
Percentage variance explained & 35.64 & 31.14 \\
Cumulative variance explained & 35.64 & 66.78 \\
\hline
\end{tabular}

Variables loadings with absolute value $>0.60$ in bold. Factor loadings greater than 0.60 in absolute value are considered to be significant (Tabachnick \& Fidell 2007) 
TABLE 3. The family, species, abbreviation used, threat status, percentage of collected fish in each species from the total collected fishes $(\% \mathrm{C})$ and percentage of fish occurrences during 13 months of sampling period $(\% \mathrm{O})$ and canonical correspondence analysis group

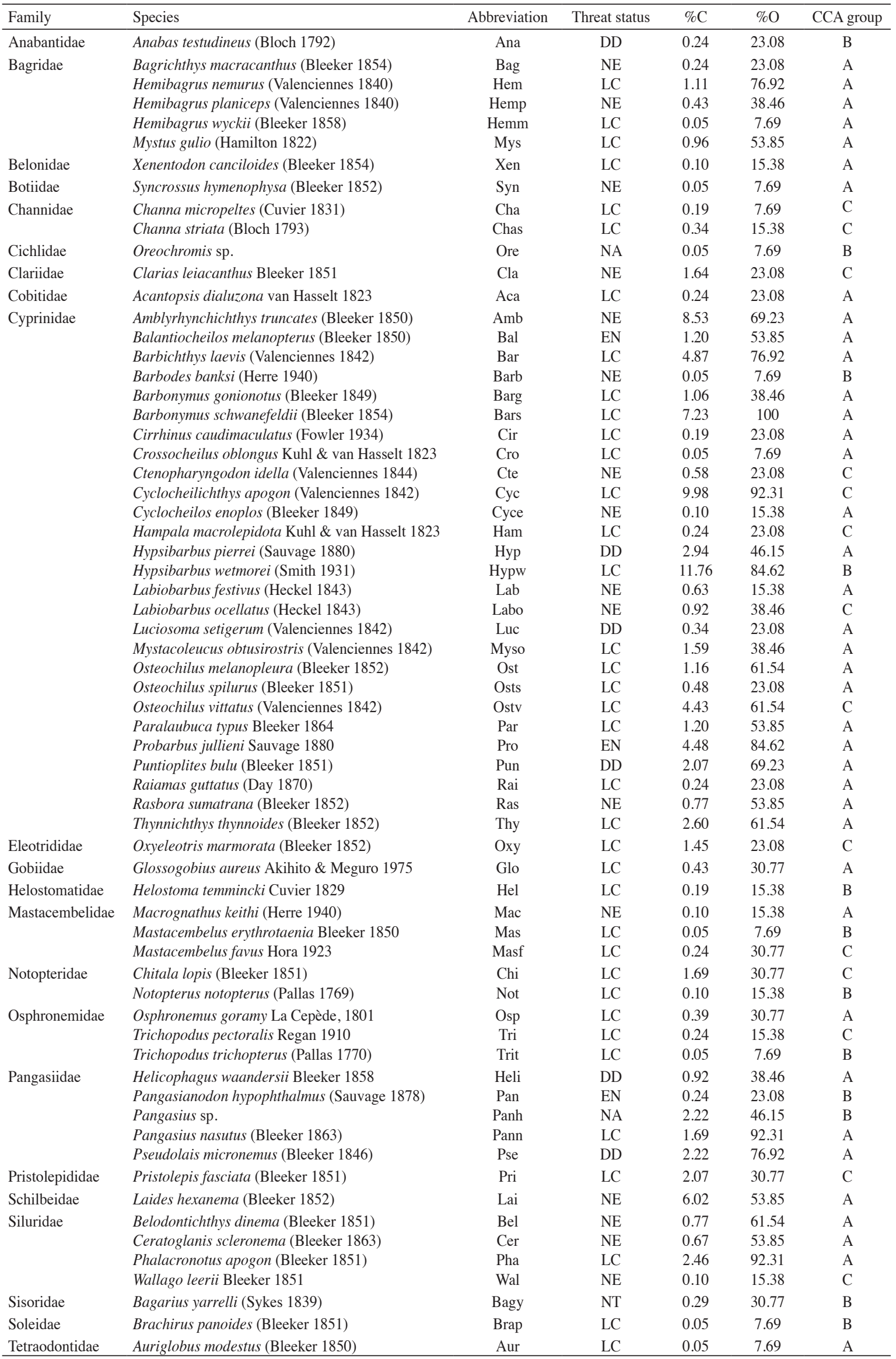


Bagridae (five species; 7.69\%), Pangasiidae (five species; $7.69 \%$ ), Siluridae (four species; 6.15\%), Osphronemidae (three species; $4.61 \%$ ), Mastacembelidae (three species; $4.61 \%$ ), Channidae (two species; $3.08 \%$ ) and Notopteridae (two species; $3.08 \%$ ). The rest of the families were only recorded with the occurrence of a single fish species (1.54\%). The species of commercially cultured fishes in Sungai Pahang, Oreochromis sp. and Pangasius sp., were also captured.

Hypsibarbus wetmorei recorded the highest frequencies of occurrence $(11.76 \% ; 244$ fish), followed by Cyclocheilichthys apogon (9.98\%; 207 fish), Amblyrhynchichthys truncates (8.53\%; 177 fish), Barbonymus schwanefeldii (7.23\%; 150 fish), Laides hexanema $(6.02 \% ; 125$ fish) and Barbichthys laevis $(4.87 \% ; 101$ fish). The rest of the species recorded less than $4.82 \%$ or 100 occurrences.

Three fish species (4.6\%), namely Balantiocheilos melanopterus, Probarbus jullieni and Pangasianodon hypophthalmus and one species (1.5\%), Bagarius yarrelli, were categorized under endangered and nearly threatened status, respectively, by The IUCN Red List of Threatened Species. A total of $9.2 \%, 24.6 \%, 56.9 \%$ and $3.1 \%$ of the collected fishes were categorized under data deficient, not evaluated, least concern and not available, respectively.

\section{RELATIONSHIPS BETWEEN WATER QUALITY, FISH OCCURRENCE, AND TIME OF SAMPLING}

The forward selection procedure for the CCA resulted in the retention of five variables as significant contributors to variation in the coordination. The first ordination axis accounted for $34.88 \%$ of the variance of the species data, whereas the second axis accounted for $31.10 \%$ of this variance (Table 4).

The CCA produced two biplots, which showed the relationships between the occurrence of fish species, water quality and time of sampling (Figure 2). Species were distributed clearly within three groups (A, B and C) with respect to the significant habitat characteristics which were supported by hierarchical analysis at a Sorensen distance of $65 \%$ similarity.

Based on the CCA ordination map, $\mathrm{pH}$ was the most important water quality variable. Temperature, conductivity and alkalinity displayed much lower importance in the structuring of the fish occurrence while phosphate displayed the lowest importance compared to other water quality variables. Thus, $\mathrm{pH}$ formed the main sample ordination gradient from the origin of coordinates.

Group A represented the biggest group which comprised of 39 fish species, followed by group $\mathrm{C}$ and $\mathrm{B}$, with 14 and 12 species, respectively. For the family of Cyprinidae, a total of $74.1 \%, 7.4 \%$ and $18.5 \%$ species were located under the group of A, B and C, respectively. The fish species under group A were mainly characterized with fishes under the family of Bagridae, Belonidae, Botiidae, Cobitidae, Gobiidae, Schilbeidae and Tetraodontidae. For group B, the fish were mainly dominated by the family Anabantidae, Cichlidae, Helostomatidae, Sisoridae and Soleidae. However, the fishes under the family of Channidae, Clariidae, Eleotrididae and Pristolepididae were dominant under group $\mathrm{C}$. Fishes under the family Pangsiidae were $60 \%$ and $40 \%$ under group A and B, respectively. A total of $75 \%$ and $25 \%$ of fish under the family of Siluridae were positioned under group A and C, respectively.

The occurrences of fishes in group A were mainly associated with high water $\mathrm{pH}$, temperature and phosphate. The occurrences of fishes in this group were mostly observed from July to October 2005 and at bimonthly intervals starting from January 2006 until July 2006. Fishes in group B were observed to be associated with high alkalinity and low water temperature. The fishes in this group were mostly captured from November to December 2005 and February 2006. For group C, the fishes were mainly observed to occur in April and June 2006 and were associated with low $\mathrm{pH}$ and phosphate environments. However, no significant pattern of fish occurrence based on the sampling months was observed.

\section{DISCUSSION}

Approximately 1,000 species of freshwater fish has been documented in the South-East Asian Tropics, whereas recently about 420 species can be found in Malaysia (Hashim et al. 2012a). From this study, a total of 65 fish species were identified from Sungai Pahang in Maran District, which could probably indicate a high diversity of the fish from upper to lower stream of the river. Even though the total number of fish species that inhibit the

TABLE 4. Canonical correspondence analysis summary statistics for water quality parameters

\begin{tabular}{lccccc}
\hline & $\mathrm{F} 1$ & $\mathrm{~F} 2$ & $\mathrm{~F} 3$ & $\mathrm{~F} 4$ & $\mathrm{~F} 5$ \\
\hline Eigenvalue & 0.38 & 0.33 & 0.17 & 0.13 & 0.07 \\
Cumulative \% & 34.89 & 65.98 & 81.34 & 93.69 & 100.00 \\
Regression coefficient & & & & & \\
$\mathrm{pH}(1-14)$ & -1.0794 & 0.4263 & 0.2873 & 0.371 & 0.406 \\
Temperature $\left({ }^{\circ} \mathrm{C}\right)$ & -0.5477 & -0.7279 & -0.2392 & -0.545 & -0.795 \\
Conductivity $(\mu \mathrm{S} / \mathrm{cm})$ & -0.4326 & -0.5392 & 0.5406 & 0.751 & 0.181 \\
Alkalinity $(\mathrm{mEq} / \mathrm{L})$ & -0.6771 & 0.5802 & 0.4340 & 0.289 & -1.053 \\
Phosphate $(\mathrm{mg} / \mathrm{L})$ & 0.2060 & -0.6996 & -1.3220 & -0.075 & -0.029 \\
\hline
\end{tabular}




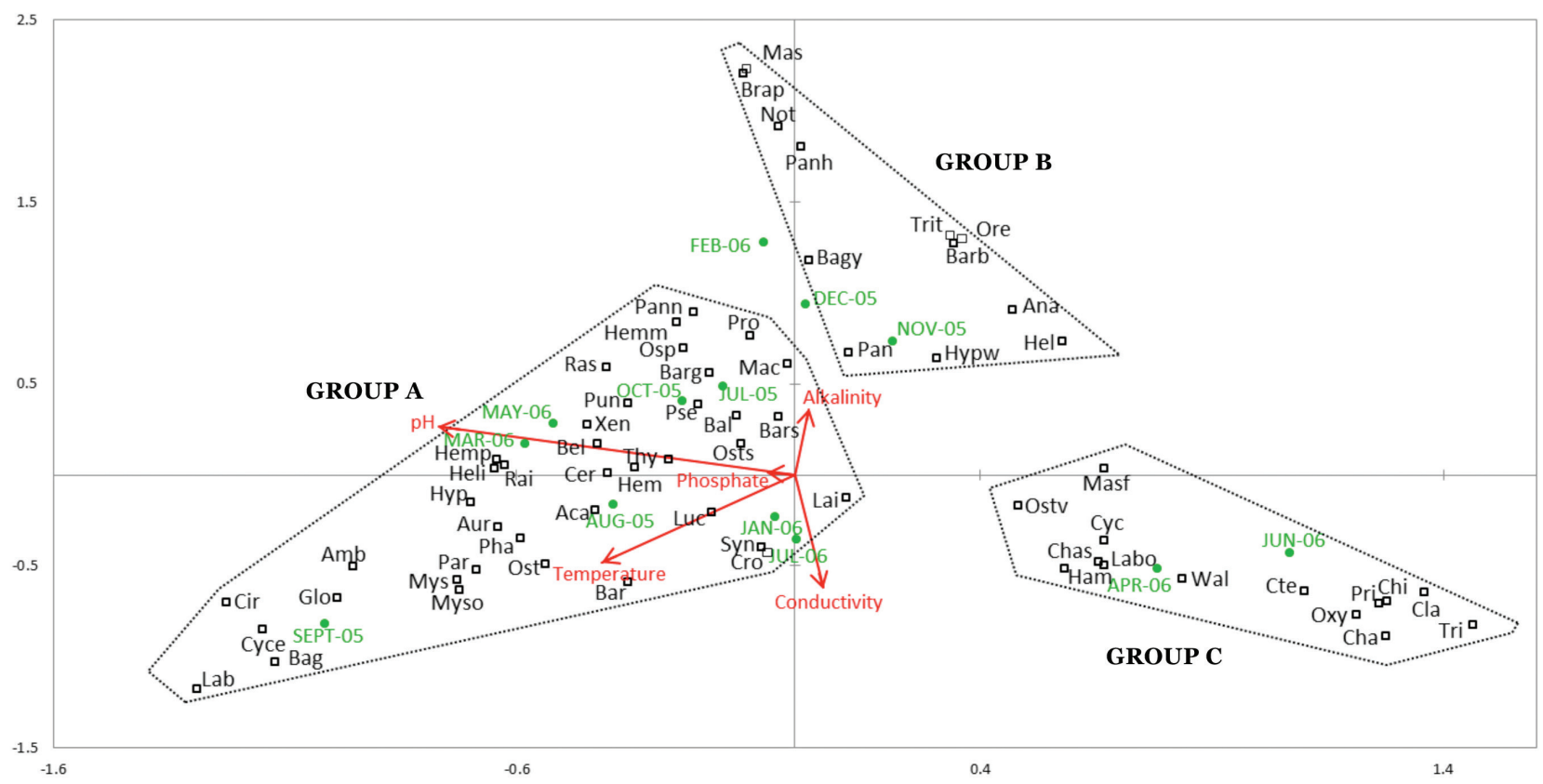

FIGURE 2. Canonical correspondence analysis ordination diagram showing the effect of significant water qualities and time of sampling on the fish occurrence

river is unknown, in the nearby area, for example along Sungai Endau, Johor, a total of 108 fish species has been documented by $\mathrm{Ng}$ and Tan (1999) and 47 species in Endau Rompin State Park, Pahang-Johor (Lim et al. 1990).

With a total of 22 different families observed, the fishes in Sungai Pahang, Maran district were dominated by the family of Cyprinidae, followed by Bagridae and Pangasiidae with 27, five and five species, respectively. Domination of the cyprinid were also observed throughout several studies in this country, such as in Sungai Keniam, Pahang (14 species or $82 \%$ ), Sungai Perak, Perak (43 species or $40.2 \%$ ), Sungai Rajang basin, Sarawak (55 species or 34\%) and combination of Sungai Enam and Sungai Telang in Temengor Reservoir, Perak (12 species or 57.1\%) (Azham \& Harinder 2011; Hashim et al. 2012a, 2012b; Parenti \& Lim 2005; Zakaria-Ismail 1994). Furthermore, the findings from this study are supported by Chong et al. (2010), which observed from a total of 1,951 species of freshwater and marine fishes belonging to 704 genera, 186 families and 37 orders recorded in Malaysia, the five most species families with $>50$ species each were Cyprinidae (150), Gobiidae (131), Pomacentridae (108), Labridae (85) and Serranidae (68).

Two endangered fish species, namely as $B$. melanopterus and P. jullieni were also identified from this study. Moreover, the collected species such as Hemibagrus wyckii, Puntioplites bulu, Helicophagus waandersii and Wallago leeri, even though not classified as endangered species by IUCN Red List of Threatened Species (IUCN 2015), we have seen a reduction of their occurrence in this country. Thus, the named species has been short-listed and were proposed as protected species for Peninsular Malaysia (Lee et al. 1993). Ismail (1992) presented some management options such as establishment of restricted areas, closed season and limiting access to fishery for conservation purposes of fisheries resources in this country. No clear pattern of fish occurrence based on the sampling months was observed for all of the groups which could indicate that the fishes were well distributed, common and abundance throughout the year (Zakaria-Ismail 1992). Moreover, there was not much difference in fish community structure throughout the year in stream that could be observed in tropical region when compared to temperate region, unless drastic human distraction and extreme natural phenomenon (drought, flood) occurred (Gorman \& Karr 1978; Ibanez et al. 2009).

The range of ammonia, nitrate, phosphate, TSS, temperature and DO readings were considered high throughout the study period. According to Montana et al. (2011) and Singh (2007), this phenomenon happened due to seasonal response to watershed geology, topography, vegetation and hydrology. As observed in our study, during the rainy season, for example for TSs, the range was very high because of the high concentration of sediments carried by the river. The high volume of water also diluted the other physico-chemical parameters observed in this study, but this was contrary (concentrated) during the dry season (Raj \& Azeez 2009).

Seasonal variations of water quality has been reported to influence the fish assemblages in various fish habitats, while the quality of the water was always related to the season and sampling time (Abrial et al. 2014; Fischer \& Paukert 2008; Li et al. 2012; Offem et al. 2009). From this study, we observed that the most important water quality variables for the fish occurrences were $\mathrm{pH}$, temperature, phosphate, conductivity and alkalinity. The physico- 
chemical variables like turbidity, temperature, DO, conductivity, TSS, $\mathrm{pH}$, ammonia and alkalinity also have been identified as important factors in structuring sites and fish assemblages in other tropical rivers (Beamish et al. 2006; Dubey et al. 2012; Sarkar \& Bain 2007; Tongnunui \& Beamish 2009; Wu et al. 2011).

Water $\mathrm{pH}$ was observed to be the main factor influencing the fish occurrence based on the length of the vector. For freshwater fish communities, $\mathrm{pH}$ can be a major determinant of which species will be present because species vary widely in their tolerance of acidity (Greig et al. 2010; Mills et al. 2000). Expose of aquatic animal to extremes of $\mathrm{pH}$ can be stressful or lethal, but the indirect effects of $\mathrm{pH}$ and interaction of $\mathrm{pH}$ with other variables are usually more important than the direct toxic effects. The optimum $\mathrm{pH}$ for growth and health of most freshwater aquatic animals is in the range 6.5 to 9.0 , while in our present study the mean of the $\mathrm{pH}(6.44 \pm 0.59)$ was still in the acceptable range. The unsuitable water $\mathrm{pH}$ could result in osmoregulation, respiration and blood acid-base balance problems in fish (Boyd \& Tucker 1998).

From this study, the water $\mathrm{pH}$ factor showed positive correlation (alkaline) with group $\mathrm{A}$, which were dominated with cyprinids, but was inversely related (acidic) to group $\mathrm{C}$ which were characterized with various family of fishes. The preference of cyprinid to alkaline water has also been observed by Rask et al. (2002) in Finnish lakes, while a study in small rivers in eastern Thailand showed that the fish species richness was negatively related to $\mathrm{pH}$ (Tongnunui \& Beamish 2009). However, in the central of the Thailand, the water $\mathrm{pH}$ did not even influence the habitat characteristics of the cyprinids of the area (Beamish et al. 2006). According to Mills (1991), different observations on $\mathrm{pH}$ preference of cyprinids might be due to their availability in high reproductive efforts, which contributed to their high abundance and perhaps facilitating colonization of unstable environments including tolerance to wide range of water $\mathrm{pH}$. Interestingly, group $\mathrm{C}$ which consisted of fish with more occurrence in acidic water such as Channa micropeltes, C. striata, Oxyeleotris marmorata, Trichopodus pectolaris, Pristolepis fasciata and W. leeri were well known for their tolerance in extreme water quality and all of them has been found in peat swamp water with very low water pH (IPT-AWB 1993; Beamish et al. 2003; Ismail et al. 2013; Shah et al. 2006).

Rocks release phosphorus as they erode under normal weather conditions. The rate at which phosphorus loads enter freshwater systems varies with land use, geology, morphology of the drainage basin, soil productivity, human activities and pollution. Phosphorus can be toxic, but toxicity occurs rarely in nature and is generally not a concern. Of more concern are the indirect effects of phosphorus. All algae and plants require phosphorus to grow. Elevated phosphorus levels, however, can increase a freshwater system's productivity and result in large amounts of organic matter falling to the bottom (CWQG 2005). However, we observed that the influence of phosphate was less important on the fish occurrence based on the length of the vectors in this study. In addition, this parameter showed positive and negative relationship with fishes in group A and C, respectively. We believed that the existence of phosphate in this water bodies might be due to the human activities along the river as previously described by Halim (2012) and Mokhlesur et al. (2011).

As a poikilothermic animal, temperature is very important in physiological and ecological activities of fishes (von Herbing 2002) and also has been observed to influence the fish assemblages in a tropical river, such as in central Thailand, Ganga basin, India and wetland of Cross River, Nigeria (Beamish et al. 2006; Dubey et al. 2012; Offem et al. 2009). Indeed, the location of this country received intense sunlight which directly increases the water temperature which sometimes can go up to $34.4^{\circ} \mathrm{C}$. In Malaysia, water temperatures fluctuate lesser compared to changes in temperate regions, which might indicate a significant factor to species occurrence in this study. Our results showed that the occurrence of fishes in group A, which is dominated by cyprinids, was also influenced by water temperature. Based on the length of the vector, this parameter was the second most important factor in influencing the fish occurrence in this area after $\mathrm{pH}$. However, this parameter was not important in occurrence of fishes in group C, but was slightly important in some of the species in group B, such as Anabas testudineus, $H$. wetmorei, Helostoma temmincki and P. hypophthalmus.

Aquatic animals do not have a significant physiological requirement for water-borne bicarbonate or carbonate, but total alkalinity is an important environmental variable in aquatic habitat because it interacts with other variables that affect the health of aquatic animal or the fertility of the ecosystem (Boyd \& Tucker 1998). Water with high alkalinities generally have a greater complement of most ions than water of low alkalinity (Moyle 1946), therefore, in unfertilized and unpolluted natural waters, correlation between alkalinity and primary production are likely related to differences in concentration of nitrogen, phosphorus and other plant nutrients rather than different concentration of bicarbonate and carbonate per se (Boyd $\&$ Tucker 1998). The occurrence of fishes in group B was significantly influenced by water alkalinity; even though was recorded as the second least strong parameter before phosphate. It has been observed that water alkalinity also played an important role in fish assemblage in other tropical river, such as in eastern and central Thailand (Beamish et al. 2006; Tongnunui \& Beamish 2009), even though the importance of alkalinity to the fishes in these rivers is not yet understood. However, the importance of alkalinity in this study was observed as it influenced the occurrence of 12 fish species from 10 different families.

Water conductivity has been reported to play a big role in influencing fish assemblages in several rivers in different regions, including tropical countries (Dubey et al. 2012; Fisher \& Paukert 2008; Tongnunui \& Beamish 2009). However, we noticed that water conductivity was 
less and inversely related with the occurrence of some fish species such as Osteochilus spirulus, B. melanopterus, Barbonymus schwanefeldii, P.jullieni and Macrognathus keithi from group A. However, no direct effect of water conductivity to fish occurrence was observed in this study, which might indicate that it is a less important parameter in influencing the occurrence of fish in this area.

\section{CONCLUSION}

This study presents new data from a study of fish assemblages and their habitat condition in Sungai Pahang, specifically located in Maran District, Pahang. Three groups of fishes that can be clearly distinguished from the CCA analysis indicated that the occurrence of fishes collected in this area were influenced by combination of water quality parameters, but not associated with sampling month. The results also provide an important database for fisheries activity and fish conservation of the river area in the future.

\section{ACKNOWLEDGEMENTS}

The authors thank to Mustafa Asmuni, Abdul Ghani Hassan, Hashim Shuhaimi, Mohd Anuar Ibrahim and Mohd Hasfairi Pauzi from Freshwater Fisheries Research Center, Fisheries Research Institute, Jelebu, Negeri Sembilan, for the sampling activities and data collection.

\section{REFERENCES}

Abrial,E., Rabuffetti,A.P., Espinola, L.A.,Amsler, M.L., Blettler, M.C.M. \& Paira, R.A. 2014. Influence of hydrological changes on the fish community in two lotic environments of the Middle Parana Floodplain, Argentina. Aquatic Ecology 48: 337-349.

Ambak, M.A., Isa, M.M., Zakaria, M.Z. \& Ghaffar, M.A. 2010. Fishes of Malaysia. Terengganu: Penerbit Universiti Malaysia Terengganu.

Angermeier, P.L. \& Winston, M.R. 1999. Characterizing fish community diversity across Virginia landscapes: Prerequisite for conservation. Ecological Applications 9: 335-349.

Azham, M.Y. \& Harinder, R.S. 2011. A study on the freshwater fish distribution of the Keniam River, Taman Negara Pahang, Malaysia. Proceeding of Rehabilitation of Tropical Rainforest Ecosystems, 24-25 October 2011, Kuala Lumpur. pp. $327-$ 333.

Beamish, F.W.H., Sa-ardrit, P. \& Tongnunui, S. 2006. Habitat characteristics of the cyprinidae in small rivers in Central Thailand. Environmental Biology of Fishes 76: 237-253.

Beamish, F.W.H., Beamish, R.B. \& Lim, S.L. 2003. Fish assemblages and habitat in a Malaysian blackwater peat swamp. Environmental Biology of Fishes 68: 1-13.

Boyd,E.C. \& Tucker, C.S. 1998. Pond Aquaculture Water Quality Management. Massachusetts: Kluwer Academic Publisher.

Brown, L.R. 2000. Fish communities and their associations with environmental variables, lower San Joaquin River drainage, California. Environmental Biology of Fishes 57: 251-269.

Canadian Water Quality Guidelines (CWQG). 2005. National Guidelines and Standards Office Environment Canada, Ottawa ON K1A 0H3.
Chong,V.C., Lee,P.K.Y. \& Lau, C.M. 2010. Diversity, extinction risk and conservation of Malaysian fishes. Journal of Fish Biology 76: 2009-2066.

Dubey, V.K., Sarkar, U.K., Pandey, A., Sani, R. \& Lakra, W.S. 2012. The influence of habitat on the spatial variation in fish assemblage composition in an unimpacted tropical River of Ganga basin, India. Aquatic Ecology 46: 165-174.

Fischer, J.R. \& Paukert, C.P. 2008. Habitat relationships with fish assemblages in minimally disturbed Great Plains regions. Ecology of Freshwater Fish 17: 597-609.

Froese, R. \& Pauly, D. 2014. FishBase.http://www.fishbase.org.

Gorman, O.T. \& Karr, J.R. 1978. Habitat structure and stream fish communities. Ecology 59: 507-515.

Greig, H.S., Niyogi, D.K., Hogsden, K.L., Jellyman, P.G. \& Harding, J.S. 2010. Heavy metals: Confounding factors in the response of New Zealand freshwater fish assemblages to natural and anthropogenic acidity. Science of the Total Environment 408: 3240-3250.

Halim, M.A.A. 2012. Upper and lower river physicochemical characteristics of Pahang river: A baseline study. Undergraduate thesis for Bachelor of Applied Science (Honours) in Industrial Chemistry, Faculty of Industrial Sciences \& Technology, Universiti Malaysia Pahang, Pahang, Malaysia.

Hashim,Z.H., Shah,A.S.R.M., Syaiful, M.M., Mansor, M. \& Sah, S.A.M. 2012b. Fishes of Sungai Enam and Sungai Telang in Temengor Reservoir, Perak, Malaysia. Check List 8: 27-31.

Hashim, Z.H., Zainuddin, R.Y., Shah, A.S.R.M., Sah, S.A.M., Syaiful, M.M., Mansor, M. 2012a. Fish checklist of Perak River, Malaysia. Check List 8: 408-413.

Haslawati, B., Chew, P.C. \& Rosly, H. 2007. Checklist of native freshwater fishes of Peninsular Malaysia. Department of Fisheries Malaysia, Ministry of Agriculture and Agro-Based Industry, Malaysia.

Humpl, M. \& Pivnička, K. 2006. Fish assemblages as influenced by environmental factors in streams in protected areas of the Czech Republic. Ecology of Freshwater Fish 15: 96-103.

Ibanez, C., Belliard, J., Hugues, R.M., Irz, P., Toham, A.K., Lamouroux, N., Tedesco, P.A. \& Oberdor, T. 2009. Convergence of temperate and tropical stream fish assemblages. Ecography 32: 658-670.

IPT-Asian Wetland Bureau (IPT-AWB). 1993. Fish sampling demonstration in north Selangor peat swamp forest. AWB Publication No. 89.

Ismail, A.K. 1992. Utilisation of freshwater fishes for aquaculture, recreational and capture fisheries in Malaysia. Proceedings of an Inception Workshop on Conservation and Management of Freshwater Fish and Their Habitats in Peninsular Malaysia. Asian Wetland Bureau Publication No.91. IPT-AWB, Kuala Lumpur.

Ismail, A., Amal, M.N.A., Abdullah, T., Johari, S., Azizul, A., Nur-Illiani, H. \& Amiruddin, M.H. 2013. Fish diversity in north Selangor peat swamp forest. Proceeding of Seminar on Scientific Biodiversity Expedition, North Selangor Peat Swamp Forest, 28th November 2013, Quality Hotel, Shah Alam, Selangor, Malaysia. pp. 57-71.

IUCN 2015. The IUCN Red List of Threatened Species. Version 2015-3. Accessed at http://www.iucnredlist.org/, 25 February 2015.

Kottelat, M. 2013. The fishes of the inland waters of Southeast Asia: A catalogue and core bibliography of the fishes known to occur in freshwaters, mangroves and estuaries. Raffles Bulletin of Zoology 27: 1-663. 
Lee, P.K.Y., Yoe, M.E. \& Khan, M.S. 1993. Data Base of Freshwater Fishes of Peninsular Malaysia. AWB Publication No. 93.

Li, J., Huang, L., Zou, L., Kano, Y., Sato, T. \& Yahara, T. 2012. Spatial and temporal variation of fish assemblages and their associations to habitat variables in a mountain stream of north Tiaoxi River, China. Environmental Biology of Fishes 93: 403-417.

Lim, K.K.P., Ng, P.K.L. \& Kottelat, M. 1990. On a collection of freshwater fishes from Endau-Rompin, Pahang-Johore, Peninsular Malaysia. Raffles Bulletin of Zoology 38: 31-54.

Magoulick, D.D. 2004. Effects of predation risk on habitat selection by water column fish, benthic fish and crayfish in stream pools. Hydrobiologia 527: 209-221.

MDC 2015. Official Portal of Maran District Council. Accessed at http://www.mdmaran.gov.my/. 23 February 2015.

Mills, C.H. 1991. Reproduction and life history. In Cyprinid Fishes: Systematics, Biology and Exploitation, edited by Winfield, I.J. \& Nelson, J.S. London: Chapman \& Hall. pp. 483-508.

Mills, K.H., Chalanchuk, S.M. \& Allan, D.J. 2000. Recovery of fish populations in Lake 223 from experimental acidification. Canadian Journal of Fisheries and Aquatic Sciences 57: 192-204.

Mokhlesur, M.R., Mohamed, A., Chowdhury, K., Jalal, A., Aisha, S. \& Kamaruzzaman, Y. 2011. Study on toxic chemicals in Kuantan (Pahang) River during pre and post monsoon season. The 24th Regional Symposium of Malaysia Analytical Sciences, 21-23 November 2011, Langkawi, Kedah, Malaysia.

Montana, C.G., Choudhary, S.K., Dey, S. \& Winemiller, K.O. 2011. Compositional trends of fisheries in the River Ganges, India. Fisheries Management and Ecology 18: 282-296.

Moyle, J.B. 1946. Some indices of lake productivity. Transactions of the American Fisheries Society 76: 322-334.

Moyle, P.B. \& Cech, J.J.J. 2003. Fishes: An Introduction to Ichthyology, 5th ed., San Francisco, California: Benjamin Cummings.

Ng, H.H. \& Tan, H.H. 1999. The fishes of the Endau drainage, Peninsular Malaysia with descriptions of two new species of catfishes (Teleostei: Akysidae, Bagridae). Zoological Studies 38: 350-366.

Offem, B.O., Samsons, Y.A. \& Omoniyi, I.T. 2009. Fish composition and abundance in the wetlands of Cross River, Nigeria. Aquatic Ecology 43: 1155-1166.

Ostrand, K.G. \& Wilde, G.R. 2002. Seasonal and spatial variation in a prairie stream-fish assemblage. Ecology of Freshwater Fish 11: 137-149.

Parenti, L.R. \& Lim, K.K.P. 2005. Fishes of the Rajang basin, Sarawak, Malaysia. Raffles Bulletin of Zoology 13: 175-208.

Pivnička, K. \& Humpl, M. 2004. Fish assemblages in the Elbe River watershed - species richness, frequency, and clusters. Acta Universitatis Carolinae Biologica 18: 107-116.

Raj, N. \& Azeez, P.A. 2009. Spatial and temporal variation in surface water chemistry of a tropical river, the River Bharathapuzha, India. Current Science 96: 245-251.

Rask, M., Olin, M., Horppila, J., Lehtovaara, A., Väisänen, A., Ruuhijärvi, J. \& Sammalkorpi, I. 2002. Zooplankton and fish communities in Finnish lakes of different trophic status: Responses to eutrophication. Verhandlungen des Internationalen Verein Limnologie 28: 396-401.
Sarkar, U.K. \& Bain, M.B. 2007. Priority habitats for the conservation of large river fishes in the Ganges River basin. Aquatic Conservation: Marine and Freshwater Ecosystems 17: 349-359.

Schiemer, F. 2000. Fish as indicators for the assessment of the ecological integrity of large Rivers. Hydrobiologia 422: 271-278.

Shah, A.S.R., Zarul, H.H., Chan, K.Y., Zakaria, R., Khoo, K.H. \& Mashhor, M. 2006. A recent survey of freshwater fishes of the Paya Beriah peat swamp forest, north Perak, Malaysia. Jurnal Biosains 17: 51-64.

Singh, I.B. 2007. The Ganges River. In Large Rivers: Geomorphology and Management, edited by Gupta, A. Hoboken, New Jersey: John Wiley \& Sons Ltd. pp. 347-371.

Smol, J.P. 2010. The power of the past: Using sediments to track the effects of multiple stressors on lake ecosystems. Freshwater Biology 55: 43-59.

Sutela, T., Vehanen, T. \& Jounela, P. 2010. Response of fish assemblages to water quality in boreal rivers. Hydrobiologia 641: 1-10.

Tabachnick, B.G. \& Fidell, L.S. 2007. Using Multivariate Statistics. 5th ed., Boston, MA: Allyn \& Bacon.

Tongnunui, S. \& Beamish, W.F.H. 2009. Habitat and relative abundance of fishes in small rivers in eastern Thailand. Environmental Biology of Fishes 85: 209-220.

von Herbing, I.H. 2002. Effects of temperature on larval fish swimming performance: The importance of physics to physiology. Journal of Fish Biology 61: 865-876.

Wildhaber, M.L., Allert, A.L., Schmitt, C.J., Tabor, V.M., Mulhern, D., Powell, K.L. \& Sowa, S.P. 2000. Natural and anthropogenic influences on the distribution of the threatened Neosho madtom in a midwestern warmwater stream. Transactions of the American Fisheries Society 129: 243-261.

Wu, J., Wang, J., He, Y. \& Cao, W. 2011. Fish assemblage structure in the Chishui River, a protected tributary of the Yangtze River. Knowledge and Management of Aquatic Ecosystems 400: 11.

Yusoff, F.M. \& Gopinath, N. 1995. The Status of Inland Fisheries in Malaysia. Indo-Pacific Fishery Commission. FAO Fisheries Report No. 512.

Zakaria-Ismail, M. 1992. Background Paper on Marine and Freshwater Fisheries, Malaysian National Conservation Strategy, Economic Planning Unit, Prime Minister's Department, Malaysia. p. 53.

Zakaria-Ismail, M. 1994. Zoogeography and biodiversity of the freshwater fishes of Southeast Asia. Hydrobiologia 285: 41-48.

Zulkafli, A.R., Asmuni, M., Hassan, A.G. \& Haslawati, B. 2014. Ikan-Ikan Air Tawar Sungai Pahang. Jabatan Perikanan Malaysia, Kementerian Pertanian dan Industri Asas Tani, Malaysia.

Zulkafli, A.R., Amal, M.N.A., Shohaimi, S., Mustafa, A., Ghani, A.H., Hashim, S., Anuar, M.I. \& Hasfairi, M.P. 2015. Length-weight relationships of 20 fish species from Pahang River, Maran district, Pahang, Malaysia. Journal of Applied Ichthyology 31: 409-410.

Zulkafli Abdul Rashid

Freshwater Fisheries Research Center

Fisheries Research Institute

71600 Jelebu, Negeri Sembilan Darul Khusus Malaysia 
Mohammad Noor Azmai Amal* \& Shamarina Shohaimi Department of Biology, Faculty of Science

Universiti Putra Malaysia

43400 UPM Serdang, Selangor Darul Ehsan

Malaysia
*Corresponding author; email: mnamal@upm.edu.my

Received: 8 May 2015

Accepted: 4 August 2016 